\title{
Nut consumption in Spain and other countries
}

\author{
Javier Aranceta $^{1,2}$, Carmen Pérez Rodrigo ${ }^{1}$, Ada Naska $^{3}$, Virginia Ruiz Vadillo ${ }^{1}$ \\ and Antonia Trichopoulou ${ }^{3}$ \\ ${ }^{1}$ Community Nutrition Unit, Bilbao Department of Public Health, Spain \\ ${ }^{2}$ Department of Preventive Medicine and Public Health, University of Navarra, Spain \\ ${ }^{3}$ Department of Hygiene and Epidemiology, School of Medicine, University of Athens, Greece
}

In countries of the Mediterranean region, nuts have been consumed in moderate quantities since ancient times. Epidemiological studies show lower risk of cardiovascular diseases in populations with frequent nut consumption, independent from other dietary components. This article assesses nut consumption in Spain and other countries using different sources of data collected at the country, household or individual levels. The per capita consumption of nuts in Spain in 2001 was $7.9 \mathrm{~g} /$ person/d. The varieties most widely consumed are walnuts, almonds, hazelnuts and peanuts. Results of the eVe study estimate an average nut consumption in the Spanish population aged 25-60 years of 3.3 g/person/d. No significant statistical differences were observed between men and women. Consumption is higher in men aged between 35 and 44 years ( $4.5 \mathrm{~g} / \mathrm{d})$ and in women aged between 45 and 54 years $(3.5 \mathrm{~g} / \mathrm{d})$. In the population of $2-24$ years, according to the enKid study, nut consumption is estimated at $4.9 \pm 18.5 \mathrm{~g} /$ person per $\mathrm{d}$. The age group with the highest consumption is teenagers between 14 and 17 years. The northeastern, northern and eastern regions of Spain show the highest consumption. According to FAO balance sheets, in 2001, Lebanon (16.5 kg/person peryear) and Greece $(11.9 \mathrm{~kg} /$ person per year) were the countries in the Mediterranean region with the highest consumption of nuts, followed by Spain $(7.3 \mathrm{~kg} /$ person per year), Israel and Italy.

Nuts: Food availability: Food consumption surveys: Trends over time: Secular trends: Sociodemographic factors

Since ancient times, nuts have formed part of the human diet and have been an important source of energy in the population groups of low socio economic level. In countries of the Mediterranean region, nuts have been present in moderate quantities in the habitual diet. The dietary pattern known as a "Mediterranean Diet" is characterized by an important consumption of cereals and its products (bread, pasta and rice), beans and vegetables, and also by the presence of nuts with olive oil as the traditional added fat for cooking (Serra-Majem et al. 2003). Fish, eggs, poultry, game and dairy products are included in lesser quantities in this dietary model.

Many epidemiological studies evidence the protective effect of the Mediterranean diet, due to the content in monounsaturated and long chain polyunsaturated fatty acids, supplied mostly by the consumption of olive oil and fish, as well as antioxidants present in fruits and vegetables. This protective effect has been shown to contribute to reducing the risk of chronic diseases such as heart disease, some types of cancer, obesity and diabetes (Kris-Etherton et al. 1999; Key et al. 2002; Fidanza, 2002; FAO WHO, 2003; Trichopoulou et al. 2003, 2005).

The nutrient content of nuts shows a high proportion of mono and polyunsaturated fatty acids. They also have other components, such as protein (arginine), fibre, copper, magnesium, vitamin E, folic acid, plant sterols and phytochemicals (Mataix et al. 1998), that have positive effects on the reduction of plasma cholesterol levels.
Epidemiological studies show a lower risk of cardiovascular diseases in populations with usual nut consumption, such as communities in the Mediterranean region, vegetarians or members of the Adventist community (Sabaté, 1999). In these studies, individuals with usual intake levels of a portion of $25 \mathrm{~g}$ of nuts more than 4-5 times a week showed a $51 \%$ decrease in the risk of ischaemic heart disease compared to the group who consumed nuts less than once a week (Fraser et al. 1992; Sabaté, 1999). The protective effect of nut consumption in relation to cardiovascular diseases seems to be independent from other dietary components.

Several studies compared the effects of a control diet (a low fat diet or a Mediterranean type diet) to a diet rich in nuts (walnuts, macadamia nuts, pistachios, pecans, almonds or peanuts) in different population groups. In most studies, a reduction of serum total and LDL cholesterol was observed in the range of $4-16 \%$ and $9-20 \%$, respectively. In addition, the levels of HDL cholesterol in serum were maintained (Kris-Etherton et al. 1999).

In a cross-over study on hypercholesterolemic patients, Zambon et al. (2000) compared the effect of a Mediterranean diet with a walnut enriced diet. The walnut diet had the same total amount of fat, since the fat from walnuts replaced part of the monounsaturated fats of the Mediterranean diet. The lipid profile improved with both diets, but the reduction of cholesterol levels was greater in the walnut enriched diet. 
Due to the effects of nuts on health, usual consumption is recommended for most of the population, apart from subjects who require a caloric restriction, due to the high energy density of nuts (Salas-Salvadó et al. 2001). Nonetheless, nut consumption is desirable for individuals with greater energy requirements (childhood, adolescence, hiking, physically active).

\section{Nut consumption in the Spanish population}

Information on nut consumption in the Spanish population is derived from several sources. Among them are food supply or food disappearance data from food balance sheets (FBS), elaborated by the Food and Agriculture Organization (FAO) of the United Nations (FAOSTAT, 2004), or by the Organization for the Economic Cooperation and Development (OECD) (OCDE, 2004). Household Budgetary Surveys carried out by the National Statistics Institutes in many countries provide useful information regarding the availability of foods in the household, nuts being one of them (Varela et al. 1971; Varela et al. 1985; Varela et al. 1995; Naska \& Trichopoulou, 2004). Furthermore, in Spain since 1987, the Ministry of Agriculture carries out an annual survey based on the 'food basket' (Dirección General de Alimentación 2003).

Also, in the last 15 years, food consumption surveys have been conducted on representative samples of the population in several regions or the whole country. These surveys provided direct information on nut consumption at the individual level (Aranceta, 2001).

\section{Food availability and supply data}

According to FAO food balance sheets (FAOSTAT, 2004), nut supply in Spain in 2001 was $7.3 \mathrm{~kg} /$ person per year (the same as $20 \mathrm{~g} /$ person perd). In this same year, the Food Basket Survey estimated the consumption of nuts at $7.9 \mathrm{~g} /$ person per d (Dirección General de Alimentación, 2003). The varieties most widely consumed were walnuts, almonds, hazelnuts and peanuts. According to the Household Budget Survey, the total nut availability in Spain in 1991 was slightly higher than $2 \mathrm{~g} /$ person per $\mathrm{d}$ and chestnuts, walnuts and almonds were the most consumed varieties (Varela et al. 1995). In the same year, the Food Basket Survey estimated the consumption at $6 \cdot 2 \mathrm{~g} /$ person per $\mathrm{d}$ and, according to FAO food balance sheets, the figure was $17.9 \mathrm{~g} /$ person per $\mathrm{d}$. It can be easily recognized that, for methodological reasons, different sources provide different estimates. Nevertheless, given that each one of these surveys is always carried out following the same procedure, the subsequent analysis of the results over the years provides interesting information to understanding trends in food consumption over time. The Household Budget and the Food Basket Surveys allow the examination/evaluation of nut consumption according to geographical regions and socioeconomic indicators.

\section{Nut consumption by age and gender groups}

Nutrition surveys carried out in different Spanish regions (the eVe study) (Aranceta et al. 2000) or the whole country (the enKid study) (Aranceta et al. 2002; Serra-Majem et al. 2003), provide information on nut consumption for different age groups and genders. The eVe study is a pooled analysis of several nutritional surveys conducted on random population samples of adults aged 25-60 years in nine Spanish regions (Aranceta et al. 1994a, 1994b; Arija et al. 1996; Serra-Majem et al. 1996, 2000; Tur \& Obrador, 2002; Vioque et al. 2003). All the surveys were conducted using similar methods for the assessment of food consumption. Databases for each survey were standardized following a homogenization protocol. Nuts used as ingredients in common recipes and products, such as breakfast cereals, were included in the estimations. The enKid study was carried out between 1998 and 2000 on a random sample of Spanish children and the youth population, aged 2-24 years.

Results of the eVe study estimate an average nut consumption in the Spanish population, aged 25-60 years, of 3.3 g/ person per $\mathrm{d}$. No differences were observed between men $(3.6 \mathrm{~g} / \mathrm{d})$ and women $(3.0 \mathrm{~g} / \mathrm{d})$. Considering consumers only, nut intake was $32 \mathrm{~g} / \mathrm{d}$ for men and $26 \cdot 8 \mathrm{~g} / \mathrm{d}$ for women. Table 1 shows nut consumption by age group in different nutrition surveys carried out in Spain and results from the eVe study.

Nuts are not typically consumed on a daily basis. There is a wide variation in levels of intake in the Spanish population. A nutrition survey of the Region of Valencia (Vioque et al. 2003 ) showed that $30 \%$ of men and $39 \%$ of women never consume nuts, or do so less than once a month. The majority of usual consumers have nuts between one and four times a month. Only $8 \%$ of men and $4 \%$ of women consume nuts daily in Valencia, one of the Spanish regions with a higher nut consumption.

Similar data was observed in the nutrition survey of the Balearic Islands (Tur \& Obrador, 2002). The greater proportion of consumers had nuts once per week, and $42 \%$ of people over the age of 45 never eat them on a usual basis. Results of the enKid study on Spanish children and young people showed a similar pattern.

By age group, the consumption is higher in men between 35 and 44 years $(4.5 \mathrm{~g} / \mathrm{d})$ and in women between 45 and 54 years ( $3.5 \mathrm{~g} / \mathrm{d})$. The Nutrition Survey of Reus showed that men aged 50-64 years and women aged 35-49 years had the highest consumption level of nuts (Arija et al. 1996).

Table 2 presents the estimated nut consumption in Spanish children and youth in the enKid study (Serra-Majem et al. 2003). In the population aged 2-24 years, nut consumption was estimated at $4.9 \pm 18.5 \mathrm{~g} /$ person per $\mathrm{d}$, with similar levels for both genders (Serra-Majem et al. 2003). The age group with the highest level of nut consumption was teenagers aged 14-17 years. In this young age group of 2-24 year olds, $82.3 \%$ showed a nut consumption of 2.6 servings/week. The types of nuts consumed most were almonds and hazelnuts. They also consumed greater quantities of sunflower seeds and peanuts, though these are not exactly nuts.

Family size relates to nut consumption patterns. Homes without children consume greater quantities of nuts in comparison to families with children. The bigger the number of individuals living in a household, the smaller the consumption of nuts (Table 3). Single person homes show an average consumption of $4.66 \mathrm{~kg} /$ person, whereas in homes with five or more members the consumption is $1.5 \mathrm{~kg} /$ person.

Regarding some aspects of life style, the eVe study (Aranceta et al. 2000) showed that men and women who 
Table 2. Nut consumption ( $g /$ person per d) in Spanish children and youths by age group. EnKid study $(1998-2000)$

\begin{tabular}{lcrc}
\hline Age group (years) & Mean & \multicolumn{1}{c}{ SD } & Median \\
\hline $2-5$ & $1 \cdot 7$ & 7.9 & 0.0 \\
$6-9$ & 3.0 & 11.3 & 0.0 \\
$10-13$ & $5 \cdot 7$ & 24.5 & 0.0 \\
$14-17$ & $6 \cdot 1$ & $20 \cdot 8$ & $0 \cdot 0$ \\
$18-24$ & 5.7 & $19 \cdot 1$ & 0.0 \\
\hline
\end{tabular}

SD: standard deviation

Source: Serra Majem (2002).

were ex-smokers consumed higher amounts of nuts. Obesity or usual active lifestyle does not significantly affect the consumption of this food group.

\section{Nut consumption patterns by geographic region and sociodemographic factors}

Educational level and geographical region are some of the sociodemographic factors that influence the consumption of nuts in Spain. In the general Spanish population (considering consumers and nonconsumers of nuts), the consumption of nuts is within the range of $1-9 \mathrm{~g} / \mathrm{d}$ depending on the geographical area. The Basque country (Aranceta et al. 1994b) and Reus (Arija et al. 1996) show the highest consumption levels. In the Canary Islands, the consumption of nuts was low, estimated at $1.9 \mathrm{~g} /$ person per d (Serra-Majem, 2000).

Men and women in the northeastern region of the peninsula, together with those in the north, showed the highest consumption of nuts, followed by the eastern region (Aranceta et al. 2000). Data on children and young people points in the same direction, the northeast and the eastern region show a greater consumption of nuts.

Data from the Food Basket Survey of the Spanish Ministry of Agriculture also shows that the regions with the highest consumption levels are Catalonia, Murcia and Valencia, all located on the eastern Mediterranean coast of the country (Fig. 1). This geographical distribution pattern of nut consumption is similar to the one portrayed in 1991 by the Household Budget Survey (Varela et al. 1995). In that survey, Cantabria in the north, Valencia in the east, and the Navarra and Murcia regions had the highest consumption levels.

Men and women with a lower educational level show a lower consumption of nuts. The influence of other sociodemographic factors, such as socio economical level, size and locality of residence and marital status, was analyzed with respect to food consumption in the eVe study (Aranceta et al. 2000). However, none of these aspects significantly affected the consumption of nuts in the adult Spanish population.

Data from the Household Budget and Food Basket surveys are consistent with the eVe study. In both cases results show that nut consumption is higher in homes where the head of the family has completed a higher educational level, compared to homes in which the head of the family has a low level of education. The opposite occurs in children and youth. According to the enKid study (Aranceta et al. 2002; Serra Majem et al. 2003), young people whose parents have a lower level of education show 
Table 3. Nut purchases in Spain (kg/per capita per year) by sociodemographic characteristics

\begin{tabular}{|c|c|c|c|c|c|}
\hline & Almonds & Peanuts & Walnuts & Other nuts & Total nuts \\
\hline \multicolumn{6}{|l|}{ Size of locality of residence } \\
\hline Less than 2000 inhabitants & 0.34 & 0.2 & 0.91 & $1 \cdot 2$ & $2 \cdot 66$ \\
\hline 2000 to 10000 & 0.15 & 0.19 & 0.42 & 1.29 & 2.04 \\
\hline 10000 to 100000 & $0 \cdot 16$ & 0.28 & 0.39 & 1.47 & $2 \cdot 31$ \\
\hline 100000 to 500000 & 0.27 & 0.24 & 0.56 & 1.42 & 2.49 \\
\hline More than 500000 & 0.17 & 0.26 & 0.47 & 1.31 & $2 \cdot 21$ \\
\hline \multicolumn{6}{|l|}{ Children in household } \\
\hline No children & 0.31 & 0.29 & 0.76 & 1.74 & 3.09 \\
\hline Children aged $<6$ years & 0.09 & 0.17 & $0 \cdot 18$ & 0.89 & 1.34 \\
\hline Children aged 6 to 15 years & 0.09 & 0.23 & 0.27 & 1.09 & 1.67 \\
\hline \multicolumn{6}{|l|}{ Family size } \\
\hline 1 & 0.34 & 0.46 & 0.93 & 2.93 & 4.66 \\
\hline 2 & 0.22 & 0.36 & 0.88 & 1.89 & 3.36 \\
\hline 3 & 0.3 & 0.25 & 0.65 & 1.3 & 2.49 \\
\hline 4 & 0.21 & 0.21 & 0.34 & 1.25 & $2 \cdot 01$ \\
\hline 5 and + & 0.08 & 0.17 & 0.24 & 1.01 & 1.5 \\
\hline \multicolumn{6}{|l|}{ Socioeconomical level } \\
\hline Low & 0.24 & 0.23 & 0.79 & 1.47 & $2 \cdot 73$ \\
\hline Mid-Low & $0 \cdot 16$ & 0.21 & 0.34 & 1.28 & 1.99 \\
\hline Midium & $0 \cdot 19$ & 0.28 & 0.46 & 1.49 & $2 \cdot 41$ \\
\hline High + mid-high & 0.25 & 0.27 & 0.45 & 1.51 & $2 \cdot 48$ \\
\hline
\end{tabular}

Source: Dirección General de Alimentación (2003).

higher nut consumption in comparison to those whose parents have completed a higher educational level.

\section{Nut consumption in other countries}

The FAO food balance sheets (FAOSTAT, 2004) show that, in 2001, Lebanon and Greece were the countries in the Mediterranean region with the highest supply of nuts, an annual average of 16.5 and $11.9 \mathrm{~kg} /$ person, respectively. Spain ranks third with $7 \cdot 3 \mathrm{~kg}$ per capita available for consumption, followed by Israel and Italy. Other countries of the Mediterranean region such as Libya, Turkey and Tunisia also have high levels of nut supply.

The Maldives islands in the Indian Ocean also show a high supply of nuts, $10 \cdot 2 \mathrm{~kg} /$ person per year. It is interesting that countries which do not grow nuts, such as Switzerland

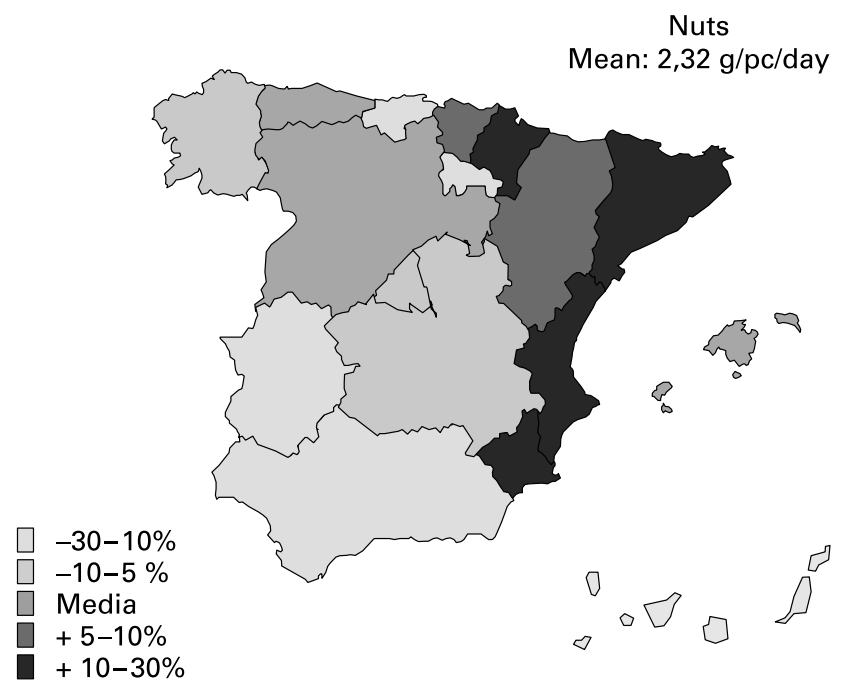

Fig. 1. Average nut consumption ( $g / p c$ per $d)$ in Spain by Region. Source: Dirección General de Alimentación, (2003).
( $8.8 \mathrm{~kg} /$ person per year), Austria, Belgium and The Netherlands, have high levels of nut supply in relation to the countries in their geographical surrounding. It is possible that the industry dedicated to the elaboration of chocolates in these countries uses a great part of the nuts that are available, although that does not mean that the manufactured products are consumed only in situ. The average supply in the 15 European Union countries is estimated at $4.9 \mathrm{~kg} /$ person per year, a higher value than the estimated average for North, Central and South America, Africa, Asia and Oceania. The average supply estimate for the whole of European countries is significantly lower, $3 \cdot 3 \mathrm{~kg} /$ person per year.

The DAFNE project (Naska \& Trichopoulou, 2004) analyzes and compares data on household food availability in different countries, on the basis of standardized information from Household Budget Surveys. For that purpose, DAFNE developed a detailed protocol for the standardization of databases and the comparable grouping of the different commodities recorded, using nationally representative samples of households in each country. After years of intense work, a wide database has been formed, which allows the on-line retrieval of comparable food availability data (http://www.nut.uoa.gr/dafnesoftweb). The latest available data refers to the end of the 1990s decade. According to DAFNE, Germany and Greece are the countries with the highest level of nut availability, an estimate of 7.5 and $4.7 \mathrm{~g} /$ person/d, respectively, followed by Norway, Portugal and Belgium This information is generally consistent with that from FAO balance sheets (Table 4).

The DAFNE databank allows for the analysis of the influence of certain sociodemographic factors. As observed in Spain, households in Greece, Portugal, Belgium, Ireland, Finland and Norway, in which the head of the household had completed higher education, show greater availability of nuts (Table 5). Distribution of nut availability levels by the occupation of the head of the household did not show a clear pattern. Neither did the locality of residence (rural $v$. urban) when analyzing the distribution of consumption. 
Table 4. Nut availability in different European countries by year of Household Budget Surveys (g/person per d)

\begin{tabular}{|c|c|c|c|c|c|c|}
\hline \multirow[b]{2}{*}{ Country } & \multicolumn{6}{|c|}{ Year of survey } \\
\hline & $1980-82$ & $1985-88$ & $1989-91$ & $1992-95$ & $1996-97$ & 1998-2000 \\
\hline Belgium & & 0.35 & & & $3 \cdot 3$ & $2 \cdot 64$ \\
\hline Finland & & 0.59 & 1.03 & & & 1.56 \\
\hline France & & 1.59 & $1 \cdot 72$ & & & \\
\hline Germany & & & & $7 \cdot 4$ & & 7.5 \\
\hline Greece & 2 & 3.71 & & & & $4 \cdot 72$ \\
\hline Ireland & & 0.92 & & 1.12 & & $1 \cdot 19$ \\
\hline Italy & & & 0.93 & 0.9 & & 0.92 \\
\hline Norway & & $3 \cdot 61$ & & $3 \cdot 32$ & $3 \cdot 8$ & \\
\hline Portugal & & & $2 \cdot 33$ & $2 \cdot 41$ & & 3.01 \\
\hline Spain & 0.9 & & 2.06 & & & 0.9 \\
\hline Sweden & & & $2 \cdot 7$ & & 1.92 & \\
\hline United Kingdom* & & 2.01 & 2.05 & & & 1.77 \\
\hline
\end{tabular}

*Weighted average based on the values for each survey year of the period. Source: The DAFNE databank (http://www.nut.uoa.gr/dafnesoftweb).

Table 5. Nut availability in different European countries by year of Household Budget Survey and level of education of household head (g/person per d)

\begin{tabular}{|c|c|c|c|c|c|c|}
\hline \multirow[b]{2}{*}{ Head of Household Education Level } & \multicolumn{6}{|c|}{ Year of survey } \\
\hline & $1980-82$ & $1985-88$ & $\begin{array}{r}1989-91 \\
\mathrm{~g} / \mathrm{p} \in\end{array}$ & $\begin{array}{l}\text { 1992-95 } \\
\text { on/day }\end{array}$ & $1996-97$ & $1998-2000$ \\
\hline \multicolumn{7}{|l|}{ Belgium } \\
\hline Elementary & & 0.32 & & & $2 \cdot 00$ & 1.75 \\
\hline Secondary & & 0.32 & & & 3.02 & 2.49 \\
\hline High & & 0.46 & & & $4 \cdot 30$ & 3.11 \\
\hline \multicolumn{7}{|l|}{ Finland } \\
\hline Elementary & & 0.49 & 1.01 & & & 1.48 \\
\hline Secondary & & 0.56 & 0.81 & & & 1.49 \\
\hline High & & 0.87 & $1 \cdot 37$ & & & 1.73 \\
\hline \multicolumn{7}{|l|}{ France } \\
\hline Elementary & & $1 \cdot 30$ & 1.79 & & & \\
\hline Secondary & & 1.82 & 1.48 & & & \\
\hline High & & $2 \cdot 07$ & $2 \cdot 19$ & & & \\
\hline \multicolumn{7}{|l|}{ Greece } \\
\hline Elementary & 1.60 & $3 \cdot 16$ & & & & 5.06 \\
\hline Secondary & 3.15 & $4 \cdot 33$ & & & & 3.96 \\
\hline High & $3 \cdot 16$ & 4.82 & & & & 5.49 \\
\hline \multicolumn{7}{|l|}{ Ireland } \\
\hline Elementary & & & & 0.71 & & 0.87 \\
\hline Secondary & & & & $1 \cdot 12$ & & $1 \cdot 12$ \\
\hline High & & & & $2 \cdot 34$ & & 1.80 \\
\hline \multicolumn{7}{|l|}{ Italy } \\
\hline Elementary & & & 0.91 & 0.89 & 0.87 & \\
\hline Secondary & & & 0.91 & 0.88 & 0.97 & \\
\hline High & & & $1 \cdot 21$ & $1 \cdot 17$ & 0.73 & \\
\hline \multicolumn{7}{|l|}{ Norway } \\
\hline Elementary & & & & 2.63 & $3 \cdot 70$ & \\
\hline Secondary & & & & 3.29 & $3 \cdot 71$ & \\
\hline High & & & & 3.85 & 4.09 & \\
\hline \multicolumn{7}{|l|}{ Portugal } \\
\hline Elementary & & & $2 \cdot 40$ & $2 \cdot 27$ & & 2.94 \\
\hline Secondary & & & 1.65 & $2 \cdot 25$ & & $3 \cdot 13$ \\
\hline High & & & 3.01 & $4 \cdot 77$ & & 3.59 \\
\hline \multicolumn{7}{|l|}{ Spain } \\
\hline Elementary & 0.85 & & 2.04 & & & 0.95 \\
\hline Secondary & 1.09 & & 2.04 & & & 0.80 \\
\hline High & $1 \cdot 21$ & & $2 \cdot 24$ & & & 0.94 \\
\hline
\end{tabular}

Source: The DAFNE databank (http://www.nut.uoa.gr/dafnesoftweb). 


\section{Secular trends of nut consumption in Spain and in other countries}

Graciani-Perez et al. (1996) studied food availability data in Spain between 1940 and 1988. These data allow for the observation of time trends in nut consumption. According to this study, consumption of nuts in Spain in 1940 was estimated at $19 \cdot \cdot 1 \mathrm{~g} /$ person per $\mathrm{d}$. Throughout the $1940 \mathrm{~s}$, nut consumption decreased to levels of $14.5 \mathrm{~g} /$ person per d, estimated in 1951. This descending trend was maintained in successive years, such that by 1970 the consumption of nuts was half that of 1940 (Fig. 2). With small oscillations, the consumption of nuts continued the downward trend and by 1988, the average consumption estimate was $5.9 \mathrm{~g} /$ person per $\mathrm{d}$.

The ongoing Food Basket Survey from the Spanish Ministry of Agriculture contains data on nut consumption since 1987, allowing assessment of time trends for the period (Direction General de Almimentación 2003). Between 1988 and 1998, the consumption of nuts in Spain followed a descending trend, with small oscillations. In the latter years, however, it seemed to recover slightly, especially through the consumption of almonds and walnuts. Between 1996 and 2001, the purchases of nuts for domestic consumption increased by $18.9 \%$, and overall, considering the consumption in restaurant establishments, increased by $13 \%$.

Analysis of data from FAO food basket sheets (FAOSTAT, 2004) leads to interesting observations. Between 1961 and 2001, the supply of nuts in the five continents followed fluctuations as shown in Table 6. Africa and South America have experienced small variations during the last 40 years. The supply of nuts in these continents has been maintained at around $1 \mathrm{~kg} /$ person per year in Africa and $0.3 \mathrm{~kg} /$ person per year in South America. In North and Central America, as well as in Asia, the supply of nuts followed an upward trend in the same period, and increased from $1.3 \mathrm{~kg} /$ person per year in 1961 to $1.9 \mathrm{~kg} /$ person per year in 2001 in North America.

In Asia, the supply of nuts increased by $60 \%$ in this period. However, trends in different countries followed different tendencies and experienced changes of different magnitude. The supply of nuts has increased considerably in Israel from 0.2 to $6.9 \mathrm{~kg} /$ person per year, and in Lebanon from $4 . \cdot 1$ to $16 \cdot 1 \cdot 1 \mathrm{~kg}$ / person per year in the last 40 years. Turkey, traditionally a producer and consumer of nuts, has maintained an average supply between 4.4 to $5.5 \mathrm{~kg} /$ person per year in the last 40 years.

European countries as a whole have maintained a steady supply of nuts, around $3 \mathrm{~kg} /$ person per year. The average nut supply for the 15 countries integrated in the European Union as of 1 May 2004 was greater than the whole European average during that period. Furthermore, it has increased considerably, from $3 \cdot 1 \cdot 1$ to $4.9 \mathrm{~kg} /$ person per year. Fig. 3 shows the supply of nuts in different European countries according to FAO food balance sheets. It is interesting to notice that countries such as Denmark, Belgium, The Netherlands, Germany, Austria and Switzerland have multiplied the supply of nuts in the last 40 years. For example, in Denmark it has risen from $0.9 \mathrm{~kg} /$ person per year in 1961 to $4.8 \mathrm{~kg}$ / person per year in 2001. Variations of similar magnitude can be observed in the other countries mentioned above. Switzerland, which already showed a high supply of nuts in $1961(5.5 \mathrm{~kg} /$ person per year), is at present one of the countries with the highest level of nut supply $(8.8 \mathrm{~kg} /$ person per year) according to FAO balance sheets. The opposite trend is

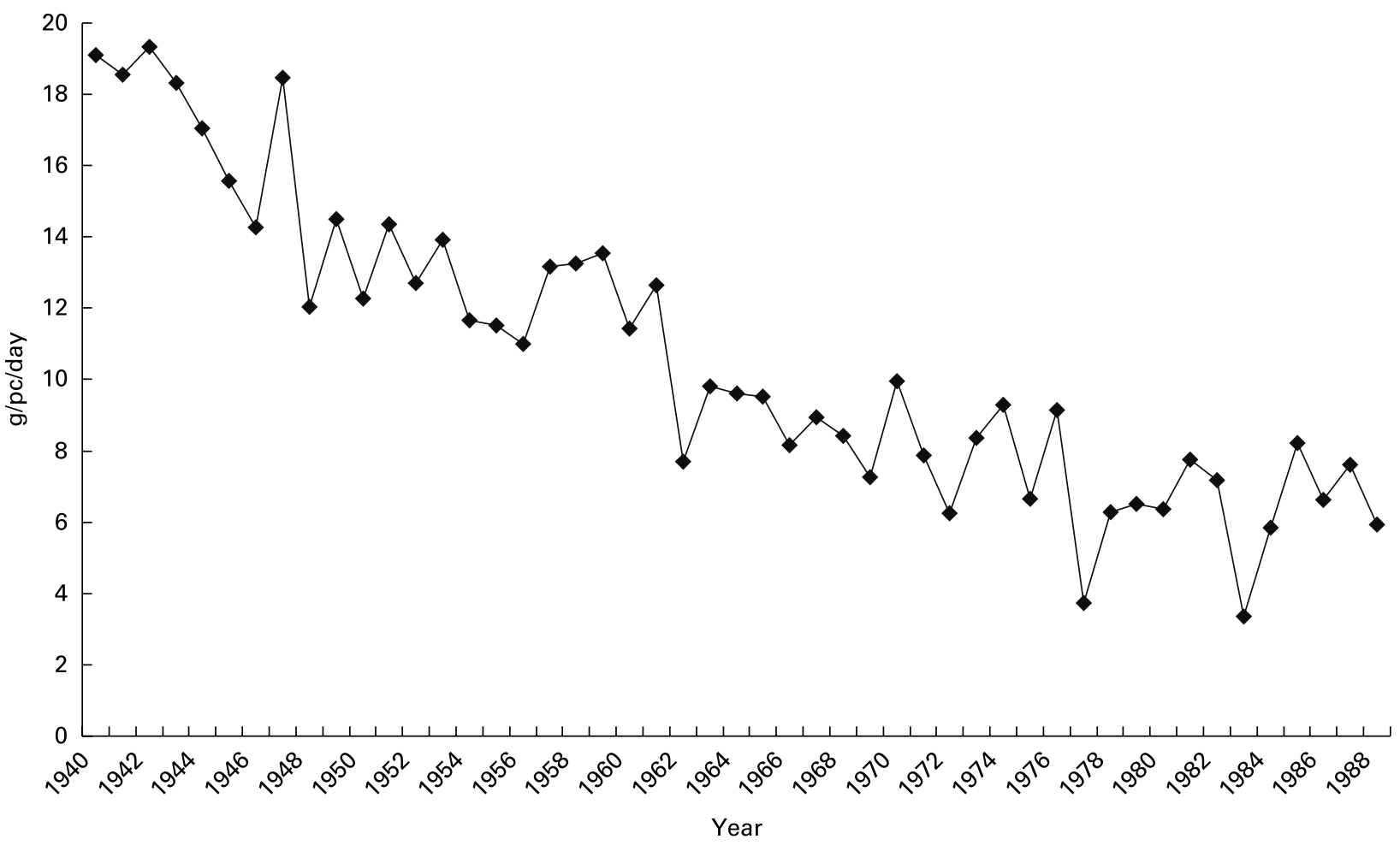

Fig. 2. Secular trends in nut consumption in Spain according to food availability data, 1940-1988. Source: Graciani-Pérez et al. 1996. 
Table 6. Secular trends of nut supply between 1961 and 2001 according to FAO Food Balance Sheets in different countries (kg/pc per year)

\begin{tabular}{|c|c|c|c|c|c|c|c|c|c|c|}
\hline \multirow[b]{2}{*}{ Countries } & \multicolumn{10}{|c|}{ Year } \\
\hline & 1960 & 1965 & 1970 & 1975 & 1980 & 1985 & 1990 & 1995 & 1998 & 2001 \\
\hline Oceania & 0.4 & 0.5 & $1 \cdot 0$ & 1.4 & $1 \cdot 2$ & $1 \cdot 8$ & 2.4 & 2.3 & $2 \cdot 5$ & $3 \cdot 2$ \\
\hline Africa & 1.0 & 1.0 & 1.0 & 0.9 & 0.8 & 0.9 & 0.8 & 0.8 & 0.9 & 1.0 \\
\hline Algeria & 0.5 & 0.5 & 0.2 & 0.3 & 0.5 & 0.9 & 0.5 & 0.7 & 0.8 & 1.0 \\
\hline Libya & 1.6 & $2 \cdot 1$ & $2 \cdot 6$ & $2 \cdot 8$ & $2 \cdot 7$ & 3.9 & $7 \cdot 5$ & $6 \cdot 2$ & $5 \cdot 8$ & $5 \cdot 7$ \\
\hline Morocco & 0.6 & 0.6 & 0.3 & 0.8 & 1.5 & $1 \cdot 3$ & $2 \cdot 1$ & 1.6 & $1 \cdot 8$ & $2 \cdot 8$ \\
\hline Tunisia & 0.9 & 0.8 & 1.0 & $2 \cdot 6$ & $4 \cdot 1$ & $5 \cdot 0$ & $5 \cdot 6$ & 4.5 & $5 \cdot 6$ & 3.3 \\
\hline North and Central America & $1 \cdot 3$ & $1 \cdot 3$ & 1.5 & $1 \cdot 6$ & $1 \cdot 3$ & $1 \cdot 7$ & $1 \cdot 8$ & 1.5 & 1.5 & 1.9 \\
\hline South America & 0.2 & 0.3 & 0.6 & 0.3 & 0.3 & 0.4 & 0.4 & 0.4 & 0.4 & 0.4 \\
\hline Asia & 0.4 & 0.4 & 0.4 & 0.5 & 0.5 & 0.6 & 0.7 & 0.9 & $1 \cdot 1$ & 1.0 \\
\hline Israel & 0.2 & 0.7 & $1 \cdot 2$ & 1.6 & $1 \cdot 2$ & 1.6 & $4 \cdot 4$ & $4 \cdot 5$ & $4 \cdot 4$ & $6 \cdot 9$ \\
\hline Lebanon & $4 \cdot 1$ & 3.8 & $4 \cdot 2$ & 3.4 & $4 \cdot 0$ & $5 \cdot 0$ & $8 \cdot 6$ & 11.4 & $15 \cdot 9$ & $16 \cdot 5$ \\
\hline Maldive islands & $7 \cdot 3$ & $6 \cdot 9$ & $7 \cdot 1$ & $7 \cdot 4$ & $7 \cdot 4$ & $8 \cdot 8$ & $10 \cdot 0$ & $9 \cdot 1$ & $9 \cdot 3$ & $10 \cdot 2$ \\
\hline Turkey & $4 \cdot 8$ & $4 \cdot 4$ & $5 \cdot 5$ & $5 \cdot 6$ & $5 \cdot 1$ & $4 \cdot 0$ & $5 \cdot 8$ & 4.9 & $4 \cdot 8$ & $5 \cdot 8$ \\
\hline European Union (15) & $3 \cdot 1$ & $3 \cdot 0$ & $3 \cdot 3$ & $3 \cdot 3$ & 3.4 & 3.5 & $4 \cdot 1$ & $4 \cdot 4$ & 4.5 & 4.9 \\
\hline Europe & $2 \cdot 7$ & $2 \cdot 7$ & $2 \cdot 9$ & $2 \cdot 8$ & $2 \cdot 9$ & $3 \cdot 0$ & $3 \cdot 4$ & $2 \cdot 7$ & $2 \cdot 7$ & $3 \cdot 0$ \\
\hline Austria & $2 \cdot 6$ & $2 \cdot 3$ & $3 \cdot 2$ & $3 \cdot 7$ & $5 \cdot 3$ & $5 \cdot 1$ & $7 \cdot 6$ & $6 \cdot 2$ & $6 \cdot 0$ & $6 \cdot 2$ \\
\hline Belgium-Luxembourg & $1 \cdot 0$ & $1 \cdot 2$ & 1.4 & $1 \cdot 8$ & $2 \cdot 6$ & $3 \cdot 1$ & $3 \cdot 3$ & $4 \cdot 3$ & $4 \cdot 6$ & $5 \cdot 0$ \\
\hline Bulgaria & $2 \cdot 2$ & $2 \cdot 9$ & $3 \cdot 1$ & $3 \cdot 0$ & $2 \cdot 6$ & $3 \cdot 4$ & $3 \cdot 5$ & 0.7 & 0.3 & 0.6 \\
\hline Denmark & 0.9 & $1 \cdot 0$ & 1.4 & $1 \cdot 4$ & $1 \cdot 7$ & $2 \cdot 3$ & $2 \cdot 7$ & $3 \cdot 3$ & $3 \cdot 8$ & $4 \cdot 8$ \\
\hline France & $2 \cdot 9$ & 3.4 & $3 \cdot 2$ & $3 \cdot 2$ & $3 \cdot 8$ & $3 \cdot 8$ & $3 \cdot 3$ & $3 \cdot 6$ & $4 \cdot 0$ & $4 \cdot 1$ \\
\hline Germany & 1.9 & $2 \cdot 1$ & $2 \cdot 1$ & $2 \cdot 5$ & $2 \cdot 8$ & $2 \cdot 9$ & $4 \cdot 4$ & $4 \cdot 8$ & $4 \cdot 4$ & $5 \cdot 0$ \\
\hline Cyprus & $5 \cdot 4$ & $6 \cdot 6$ & $7 \cdot 7$ & $5 \cdot 6$ & $5 \cdot 8$ & $3 \cdot 3$ & $4 \cdot 3$ & $7 \cdot 6$ & $3 \cdot 9$ & 3.3 \\
\hline Greece & $8 \cdot 3$ & $7 \cdot 3$ & 7.4 & $9 \cdot 1$ & 8.5 & $8 \cdot 7$ & $9 \cdot 4$ & $10 \cdot 4$ & $9 \cdot 4$ & 11.9 \\
\hline Ireland & 0.7 & 0.4 & 0.9 & $1 \cdot 2$ & $1 \cdot 2$ & 1.5 & 0.8 & 0.6 & $0 \cdot 8$ & 0.9 \\
\hline Italy & $5 \cdot 1$ & $5 \cdot 2$ & $5 \cdot 8$ & 4.5 & $5 \cdot 1$ & 4.4 & 4.9 & $5 \cdot 6$ & $6 \cdot 4$ & $6 \cdot 1$ \\
\hline Malta & $1 \cdot 2$ & 1.5 & 0.9 & $1 \cdot 2$ & $1 \cdot 3$ & $2 \cdot 1$ & $3 \cdot 1$ & $2 \cdot 8$ & $3 \cdot 1$ & $4 \cdot 2$ \\
\hline The Netherlands & 0.9 & $1 \cdot 0$ & $1 \cdot 3$ & $2 \cdot 1$ & 0.3 & 0.2 & $3 \cdot 1$ & $5 \cdot 1$ & $5 \cdot 3$ & 5.9 \\
\hline Norway & $1 \cdot 7$ & 1.4 & $1 \cdot 8$ & $2 \cdot 0$ & $2 \cdot 2$ & $3 \cdot 0$ & $2 \cdot 9$ & $2 \cdot 8$ & 2.9 & $2 \cdot 9$ \\
\hline Portugal & $9 \cdot 7$ & $6 \cdot 0$ & $11 \cdot 8$ & 4.5 & $2 \cdot 7$ & $3 \cdot 1$ & 3.5 & $3 \cdot 1$ & 3.5 & $4 \cdot 2$ \\
\hline Spain & $6 \cdot 2$ & $5 \cdot 3$ & $6 \cdot 0$ & 7.5 & $6 \cdot 6$ & $6 \cdot 8$ & $7 \cdot 1$ & $6 \cdot 0$ & $6 \cdot 5$ & $7 \cdot 3$ \\
\hline Sweden & $1 \cdot 7$ & $2 \cdot 2$ & $2 \cdot 2$ & $2 \cdot 5$ & 2.9 & 2.9 & $2 \cdot 6$ & $3 \cdot 1$ & $2 \cdot 6$ & $2 \cdot 2$ \\
\hline Switzerland & $5 \cdot 6$ & $5 \cdot 7$ & $5 \cdot 9$ & $6 \cdot 3$ & $7 \cdot 3$ & $7 \cdot 8$ & $7 \cdot 6$ & $7 \cdot 9$ & $8 \cdot 0$ & $8 \cdot 8$ \\
\hline United Kingdom & $1 \cdot 2$ & $1 \cdot 1$ & $0 \cdot 8$ & 0.7 & 0.7 & $1 \cdot 0$ & 1.5 & 1.6 & 1.4 & 1.9 \\
\hline
\end{tabular}

Source: FAOSTAT, 2004. At URL http://www.faostat.org



Fig. 3. Nut supply in Europe in 2001. Source: FAOSTAT, 2004. 
observed in Portugal, a country where the nut supply in 1961 was estimated at $9.7 \mathrm{~kg} /$ person per year. It has followed a downward trend to $4.2 \mathrm{~kg} /$ person per year in 2001 .

In Greece, Spain and Italy, nut supply has increased throughout the years. Greece has maintained itself as the country with the highest levels and has increased from 8.3 to $11.9 \mathrm{~kg} /$ person per year. In Spain, according to FAO balance sheet data, nut supply increased from $6.2 \mathrm{~kg} /$ person per year in 1961 to $7.3 \mathrm{~kg} /$ person per year in 2001. France, which occupies a more discrete place in the rank order, also slightly increased nut supply in the same period and rose from 2.9 to $4.4 \mathrm{~kg} /$ person per year.

\section{Forms of consumption and utilization of nuts in the Spanish population}

Nuts are consumed in Spain in different forms, although consumption as a between meals snack is very common. They are also consumed as a part of other processed products, which include peeled, toasted, fried, and salted nuts in their composition. Nuts are also used as ingredients in culinary preparations. Through the preparation process, the texture is modified and the flavour and aroma of nuts are boosted. In most cases, nuts in Spain are not consumed as raw products, except for walnuts and pine nuts. They are more frequently consumed toasted, grilled or fried.

Walnuts are usually either consumed by themselves or as an ingredient in sauces, ice creams and pastries. Pine nuts are also consumed as a part of pastry products, sweets, and salads, as well as raw or toasted. Pine nuts are used as an accompanying ingredient in some dishes, for example spinach with raisins and pine nuts.

Almonds and hazelnuts are usually consumed raw, toasted, grilled, fried or sugared as candy almonds. They can also be added to sweet dishes, salads, in sauces, pates, and ice cream. A traditional sauce, the 'ajoblanco', lists almonds as an ingredient. The Catalan kitchen widely uses a 'picada' in many traditional dishes. This is made of a mashed mixture of almonds and hazelunts, garlic and toasted bread. This mixture forms a homogenized paste which is added to stews and other preparations when they are almost cooked (Caius Apicius, 2003)

Almonds are a main ingredient in many traditional sweets such as 'turron' (nougat) and marzipan. They are widely used in pastries. Almonds are also used, although less commonly, to prepare palatable nutritious products such as 'almond milk' or almond concentrate, which can be used as a milk substitute in some cases, or as a dietary supplement.

Chestnuts are a nut variety common in the Cantabric coast and in Galizia. In former times they were a very important source of energy in the diet of these regions. With the introduction of potatoes their consumption dropped and was replaced by the new American product. Chestnuts can be consumed raw, although it is not common. The most frequent preparations are toasted, roasted, grilled, or cooked in the form of puree, marmalades, and 'marron glasse' (Caius Apicius, 2003).

Pastries, dough, cookies, candies and chocolates frequently incorporate nuts in the list of ingredients. Chocolate cream with hazelnuts and almonds are other popular delicacies.
Nowadays, nuts are often used in the preparation of different culinary recipes, such as some typical sauces (romesco sauce, pesto, 'picada'). They are used in soups, creams and salads, and also accompany meat or fish dishes. Other frequent forms of consumption include desserts made with yogurt, quince or accompanying cheese platters (cheese with walnuts and grapes).

Nuts have an important gastronomic value. They add a distinctive touch of flavour, provide a different texture to dishes and can contribute a touch of colour. These organoleptic qualities are widely used in the Mediterranean kitchen.

\section{References}

Aranceta Bartrina J (2001) Nutrición Comunitaria, $2^{\mathrm{a}}$ edición, Barcelona: Masson.

Aranceta Bartrina J, Serra Majem L1, Pérez Rodrigo C, et al. (2000) Las vitaminas en la alimentación de los españoles. Estudio eVe. Análisis en población general. In Libro blanco. Las vitaminas en la alimentación de los españoles. Estudio eVe, pp. 49-94 [J Aranceta, Ll Serra Majem, RM Ortega, A Entrala and A Gil, editors]. Madrid: Panamericana.

Aranceta Batrina J, Pérez Rodrigo C, Ribas Barba L \& Serra Majem L1 (2002) Factores determinantes de los hábitos de consumo alimentario en la población infantil y juvenil española. In Alimentación infantil y juvenil. Estudio enKid, pp. 29-40 [L1 Serra Majem and J Aranceta Bartrina, editors]. Barcelona: Masson.

Aranceta J, Pérez C, Amela C \& García Herrera R (1994a) Encuesta de Nutrición de la Comunidad de Madrid. Madrid: Consejería de Salud de la Comunidad de Madrid.

Aranceta J, Pérez C, Marzana I, Eguileor I, González de Galdeano L \& Saenz de Buruaga J (1994b) Encuesta de Nutrición de la Comunidad Autónoma Vasca. Tendencias de consumo alimentario, indicadores bioquímicos y estado nutricional de la población adulta de la Comunidad Autónoma Vasca. Vitoria: Gobierno Vasco.

Arija V, Salas J, Fernández J, Cucó G \& Martí-Henneberg C (1996) Consumo, hábitos alimentarios y estado nutricional de la población de Reus (VIII): Evolución del consumo de alimentos, de su participación en la ingesta de energía y nutrientes y de su relación con el nivel socioeconómico y cultural entre 1983 y 1993. Med Clin (Barc) 106, 174-179.

Caius Apicius. Gastronomía: Frutas secas, frutos secos. La Revista de Libertad Digital. 25 de Abril de 2003.

Dirección General de Alimentación (2003) La alimentación en España, 2001. Madrid: Ministerio de Agricultura Pesca y Alimentacios.

FAOSTAT. Available at URL: [http://www.faostat.fao.org] Accessed on April 29th 2004.

FAO/ WHO (2003) Diet, nutrition and the prevention of chronic diseases. Report of a Joint FAO/ WHO Expert consultation. WHO Technical report series 916. Geneva: WHO.

Fidanza F (2002) La dieta mediterránea y la salud: El Estudio de los Siete Países. In: Qué es la dieta mediterránea?, pp. 21-36 [L1 Serra Majem and J Ngo de la Cruz, editors]. Barcelona: Nexus ediciones- FDDM.

Fraser GE, Sabaté J, Beeson WL \& Strahan TM (1992) A possible protective effect of nut consumption on risk of coronary Herat disease: the Adventist Healt Study. Arch Intern Med 152, 1416-1424.

Graciani Pérez-R A, Rodríguez Artalejo F, Banegas Banegas JR, Hernández Vecino R \& del Rey Calero J (1996) Consumo de alimentos en España en el periodo 1940-1988. Madrid: Ediciones UAM.

Key TJ, Allen NE, Spencer EA \& Travis RC (2002) The effect of diet on risk of cancer. Lancet 360, 9336, 861-868. 
Kris-Etherton PM, Yu-Poth S, Sabaté J, Ratcliffe HE, Zhao G \& Etherton TD (1999) Nuts and their bioactive constituents: effects on serum lipids and other factors that affect disease risk. Am J Clin Nutr 70, 504S-511S.

Mataix J, Mañas M, Llopis J \& Martinez de Victoria E (1998) Tabla de composición de alimentos españoles, $3^{\mathrm{a}} \mathrm{ed}$, Granada: Universidad de Granada.

Naska A, Trichopoulou, A for The DAFNE databank (DATA FOOD NETWORKING). Available at URL: [http://www.nut.uoa.gr/ english/dafne/Dafne EN.htm] Accessed on April 29 ${ }^{\text {th }}, 2004$.

OCDE (2004). Producer and consumer support estimates, OECD database 1986-2002. Available at URL: [http://www.OECD.org/ home] Accessed on April 29 2004.

Sabaté J (1999) Nut consumption, vegetarian diets ischemic heart disease risk and all-cause mortality: evidence from epidemiologic studies. Am J Clin Nutr 70, 500S-503S.

Salas Salvadó, J, Megías Rangil, I, Arija Val, V, et al. (2001). Frutos secos. En: Sociedad Española de Nutrición Comunitaria (SENC). Guías alimentarias para la población española. Recomendaciones para una dieta saludable. Madrid: IMC \& SENC: 87-94.

Serra Majem Ll (Director) (2000). Encuesta Nutricional de Canarias, ENCA, 1997-1998. (Vol. 1-5). Servicio Canario de Salud. Santa Cruz de Tenerife.

Serra Majem L1 (2002) La dieta mediterránea y el siglo XXI. In: Qué es la dieta mediterránea?, pp. 205-219 [L1 Serra Majem and J Ngo de la Cruz, editors]. Barcelona: Nexus ediciones- FDDM.

Serra Majem L, Ribas Barba L, García Closas R, et al. Avaluació de l'estat nutricional de la població catalana (1992-93). Avalauació dels hàbits alimentaris, el consum d'aliments, energia $i$ nutrients, $i$ de l'estat nutricional mitjançant indicadors bioquímics $i$ antropomètrics, Barcelona: Generalitat de Catalunya. Departament de Sanitat i Seguretat Social.
Serra-Majem Ll, Ribas Barba L, Pérez Rodrigo C, Román Viñas B \& Aranceta Bartrina J (2003) Hábitos alimentarios y consumo de alimentos en la población infantil y juvenil española (1998-2000): variables socioeconómicas y geográficas. Med Clin (Barc) 121, 126-131.

Trichopoulou A, Naska A, Orfanos Ph \& Trichopoulos D (2005) Mediterranean diet in relation to body mass index and waist-tohip ratio: the Greek European Prospective Investigation into Cancer and Nutrition Study. Am J Clin Nutr 82, 935-940.

Trichopoulou A, Costacou T, Bamia C \& Trichopoulos D (2003) Adherence to a Mediterranean diet and survival in a Greek population. $N$ Engl J Med 348, 2599-2608.

Tur JA \& Obrador A (dirs) (2002) Estudio de Nutrición de las Islas Baleares. (ENIB, 1999-2000). Libro blanco de la alimentación y la nutrición en las Islas Baleares. Volumen II. Rev Cien IEB 28, 1- 120.

Varela G, García D \& Moreiras O (1971) La nutrición de los españoles, diagnóstico y recomendaciones. Madrid: Instituto de Desarrollo Económico, Escuela Nacional de Administración Pública.

Varela G, Moreiras O, Requejo A. (1985). Estudios sobre nutrición (Vols. 1 y 2). Madrid: Instituto Nacional de Estadística.

Varela G, Moreiras O, Carbajal A \& Campo M (1995) Encuesta de presupuestos familiares 1990-91. Estudio Nacional de Nutrición y Alimentación, 1991. Tomo I. Madrid: Instituto Nacional de Estadística.

Vioque López J \& Quiles Izquierdo J, Encuesta de nutrición y salud de la Comunidad Valenciana, editors].Alicante: Departamento de Salud Pública, Historia de la Ciencia y Ginecología. Universidad Miguel Hernández.

Zambón D, Sabaté J, Muñoz S, et al. (2000) Substituting walnuts for monounsaturated fat improves the serum lipid profile of hyperhcolesterolemic men and women. A randomized crossover trial. Ann Intern Med 132, 538-546. 